\title{
Impact of Hijlan Creek springs on water quality of the Euphrates River and the Hydrochemical characterization of the contamination plumes
}

Muwafaq Ayesh Rabeea

University of Anbar

Ahmed J. R. Al-Heety

University of Anbar

Mahmmoud Ismail Mohammed

University of Mosul

Adnan Mohammed Fayydh

University of Anbar

Mohamed Elhag ( $\nabla$ melhag@kau.edu.sa )

King Abdulazziz University https://orcid.org/0000-0001-9048-0084

\section{Research Article}

Keywords: Balneotherapy, Contamination, Spring waters, River-Creek confluence, Re-aeration

Posted Date: June 2nd, 2021

DOl: https://doi.org/10.21203/rs.3.rs-338406/v1

License: (c) (i) This work is licensed under a Creative Commons Attribution 4.0 International License.

Read Full License

Version of Record: A version of this preprint was published at Environmental Earth Sciences on July 19th, 2021. See the published version at https://doi.org/10.1007/s12665-021-09749-6. 


\title{
Impact of Hijlan Creek springs on water quality of the Euphrates River and the
}

\section{Hydrochemical characterization of the contamination plumes}

\section{Muwafaq Ayesh Rabeea*1, Ahmed J. R. Al-Heety², Mahmmoud Ismail Mohammed ${ }^{3}$, Adnan Mohammed Fayydh ${ }^{4}$ and Mohamed Elhag ${ }^{* 5,6,7}$,}

${ }^{1}$ Department of Applied Chemistry, College of Applied Sciences, University of Anbar. Hit, Anbar 31007. Iraq.

${ }^{2}$ Seismic Processing Center/ Oil Exploration Company/ Baghdad-Iraq.

${ }^{3}$ Department of Biology, College of Science, University of Mosul, Iraq

${ }^{4}$ Department of Chemistry, College of Pure Sciences, University of Anbar.

${ }^{5}$ Department of Hydrology and Water Resources Management, Faculty of Meteorology, Environment \& Arid Land Agriculture, King Abdulaziz University Jeddah, 21589. Saudi Arabia.

${ }^{6}$ Institute of Remote Sensing and Digital Earth (RADI), Chinese Academy of Science (CAS), Beijing, 100094, China.

${ }^{7}$ Department of Applied Geosciences, Faculty of Science German University of Technology in Oman, Muscat, 1816, Oman.

*Corresponding emails: muw88@uoanbar.edu.iq; and melhag@kau.edu.sa

\begin{abstract}
This work aims to present the hydrochemical mechanisms describing the system of the Euphrates River before and after mixing with groundwater from the springs of Hijlan (western Iraq). Continuously, the data generated from these springs' water have been adapted to provide an updated assessment for future water therapeutic purposes. Physicochemical characteristics of water in the mixing plume of Hijlan Creek and the Euphrates indicate the multi Hydrochemical plumes as revealed by the spatial variation of important parameters related to the ecological parameters including $\mathrm{K}^{+}, \mathrm{Na}^{+}, \mathrm{Ca}^{+2}, \mathrm{Mg}^{+2}, \mathrm{HCO}^{3-}, \mathrm{SO}_{4}^{-2}, \mathrm{Cl}^{-}, \mathrm{NO}^{3-}, \mathrm{PO}_{4}^{-3}, \mathrm{~Pb}^{-}$ $\mathrm{Zn}, \mathrm{Cd}, \mathrm{Fe}, \mathrm{Mn}$, Temp, DO, BOD $5, \mathrm{H}_{2} \mathrm{~S}$, Turbidity, EC, pH, and TDS. The re-aeration $\left(\mathrm{k}_{2}\right)$ and de-oxygenation rate $\left(\mathrm{k}_{1}\right)$ coefficients, as well as the self-purification factor (f) of the mixing plume, are $0.51 \mathrm{sec}^{-1}, 2.03 \mathrm{sec}^{-1}$, and 0.25 , respectively. The $\mathrm{Cl}^{-}$concentration in the confluence zone changes, due to the chloride content mixing rates of $7.1 \%$ and $92.9 \%$ for Euphrates and Hijlan creek water, respectively, with water discharge of $316,224 \mathrm{~m}^{3} /$ day and chloride load discharge of 420 tons/day. The assessment of the water quality indicates unsuitability for aquaculture purposes. However, the water can be used for therapeutic purposes and to cure multiple diseases.
\end{abstract}


Keywords: Balneotherapy; Contamination; Spring waters; River-Creek confluence; Reaeration

\section{Introduction}

Environmental concerns are growing with variations in water resource pollutants. Numerous rivers are vulnerable to disasters due to the increase of pollutants (Gurnell et al., 2020; Muwafaq et al., 2020). Rivers water has traditionally been seen as a disposal site for waste coming from a variety of activities, believing that a large amount of water by dilution leads to detoxification (Tuyet et al., 2020; Vandana et al., 2020). Contamination of the rivers is one of the greatest challenges facing the new world, which is creating an unsettling situation. Increased human activities and natural resources (groundwater and spring water) flowing into rivers make it necessary to evaluate the current water quality of rivers and predict potential improvements (Gao et al., 2019; FregosoLópez et al., 2020). The water quality indexes may be divided into specified indicators, public indicators, planning and designing indicators, and statistical indicators. Statistical models are significantly important when evaluated water quality (Marta et al., 2010; Jena et al., 2013; Cruz et al., 2019).

The surface and groundwater resources of the study area have been covered by several previous reports (Fayadh et al., 2016; Bayan et al., 2020). Techno promo export (1978) studied the groundwater and surface water resources in the study area, which was the basis for establishing Haditha Dam. The Consortium Yugoslavia (1981), performed hydrogeological tests to explore the water resources within block 7 in the Western Desert. Al-Hadithi (1994) studied the hydrology of the Haditha reservoir and pointed out the contribution of Haditha lake and groundwater recharge. Al Jabbari et al., (2002) studied the Euphrates basin within the national monitoring program, which includes the groundwater adjacent to the Euphrates River. Al-Hadithi (2005) reported the variation in the hydrochemical characteristics of Hijlan springs and some wells in 
the Haditha area. Hussein (2010) utilized the intersection of groundwater with surface water to describe the movement and levels of the groundwater along the Euphrates river in Al-Anbar province. A statistical study of the source and origin of the hydro-chemical constituents in the Euphrates River from Al-Qa'im District to Al-Baghdadi city was conducted via government observation during water surplus and deficit periods in 2007 (Al Hamdani et al., 2012).

The Euphrates River has been exposed to decades-old hazards of contamination from continuous groundwater discharge as flowing springs (Hijlan springs) dispose into the river. A feasible program of field monitoring was conducted to obtain the ambient water quality data in the mixing zone of the Euphrates, which was formed in a restricted confluence region due to Hijlan creek discharge. The Creek water behaves as a plume of a point source or minero-medicinal water but can be considered a point source of pollution due to the inflow of salts additives, ions, and other elements into the Euphrates. Therefore, it is necessary to assess the degradation degree of the river contamination in the confluence zone. This study is an attempt to determine the characteristics of the Euphrates River water before and after mixing with Hijlan springs creek (statistical and spatial evaluation). Besides, investigate the amount of total load added to the Euphrates and the mixing case using the chloride concentration. Continuously, the variation of the concentration of chemical components within the deterioration plume, the aeration phenomenon using the dissolved oxygen concentration, the possibility of using spring mineral water for therapeutic purposes, recreation after improvement, and environmental regulation of the Hijlan Creek are investigated.

\section{Study area}

Hijlan Springs are found in the confluence region of Hijlan Creek with Euphrates River, locating at a distance of approximately $3 \mathrm{Km}$ north of Haqlaniyah town, Haditha provinces, Al-Anbar Governorate, bounded by UTM Northing of 255000 to 260000 and Easting of 3773000 and 
3777000, (Figure 1). The mean annual temperatures, rainfall, evapotranspiration during (19702017) of Hijlan Springs were $21.9{ }^{\circ} \mathrm{C}, 138.9 \mathrm{~mm}$, and $3088 \mathrm{~mm}$, respectively. The climate in the study area is arid based on the classification of Mather (1974).

Aridity index $(\mathrm{AI})=\{(P / P E)-1)\} / 100$

Where: AI denotes Aridity Index, $\mathrm{P}$ signifies rainfall $(138.9 \mathrm{~mm})$, PE represents Evapotranspiration (3088 mm).

Geologically the area covered by sedimentary rocks is aged from the late Oligocene to Early Miocene (Sissakian and Hafidh, 1994), represented by the Anah and Euphrates Formations that are exposed near Haqlaniyah town in the deep cutting of Hijlan valley. Anah Formation (Upper Oligocene is composed mainly of massive bedded and hard dolomitic limestone and cavernous limestone, which are locally strongly Karastified resulting in the formation of differently sized cavities (Sissakian and AL-Mousawi, 2007). The exposed formation has an approximate thickness of $6-10 \mathrm{~m}$. The Anah formation is overlain unconformably by the Euphrates formation (Lower Miocene), which is composed of early Miocene sediments. Euphrates formation is exposed along both banks of the Euphrates River.

The formation changes in both horizontal and vertical directions. It consists of two members. Lower Member consists of basal conglomerate, which plays a big role in water circulation and development of the sinkholes. The conglomerate is overlain by well-bedded and hard dolomitic limestone, dolomite, and limestone; followed by thickly bedded chalky limestone; upwards become thinly bedded. This succession forms all the flat areas and all the sinkholes are developed in the succession (Mahdi, et al. 1985), with a thickness range of 5 to $25 \mathrm{~m}$. The upper member consists of brecciated and highly deformed limestone, dolostones, and dolomitic limestone with horizons and lenses of green mud, and a thickness range of 7 to $15 \mathrm{~m}$ (Figure 1). These Formations are covered by residual soil and/or alluvial soil (Gypsious and Calcareous soils). Karst 
phenomenon including landforms, Sinkholes karst types, caves is the most common karst forms in the study area. Surface karstification is manifested as numerous sinkholes and shallow holes of regular shapes and vertical wells depressions (Abdul Razzak and Zaynal, 2012).

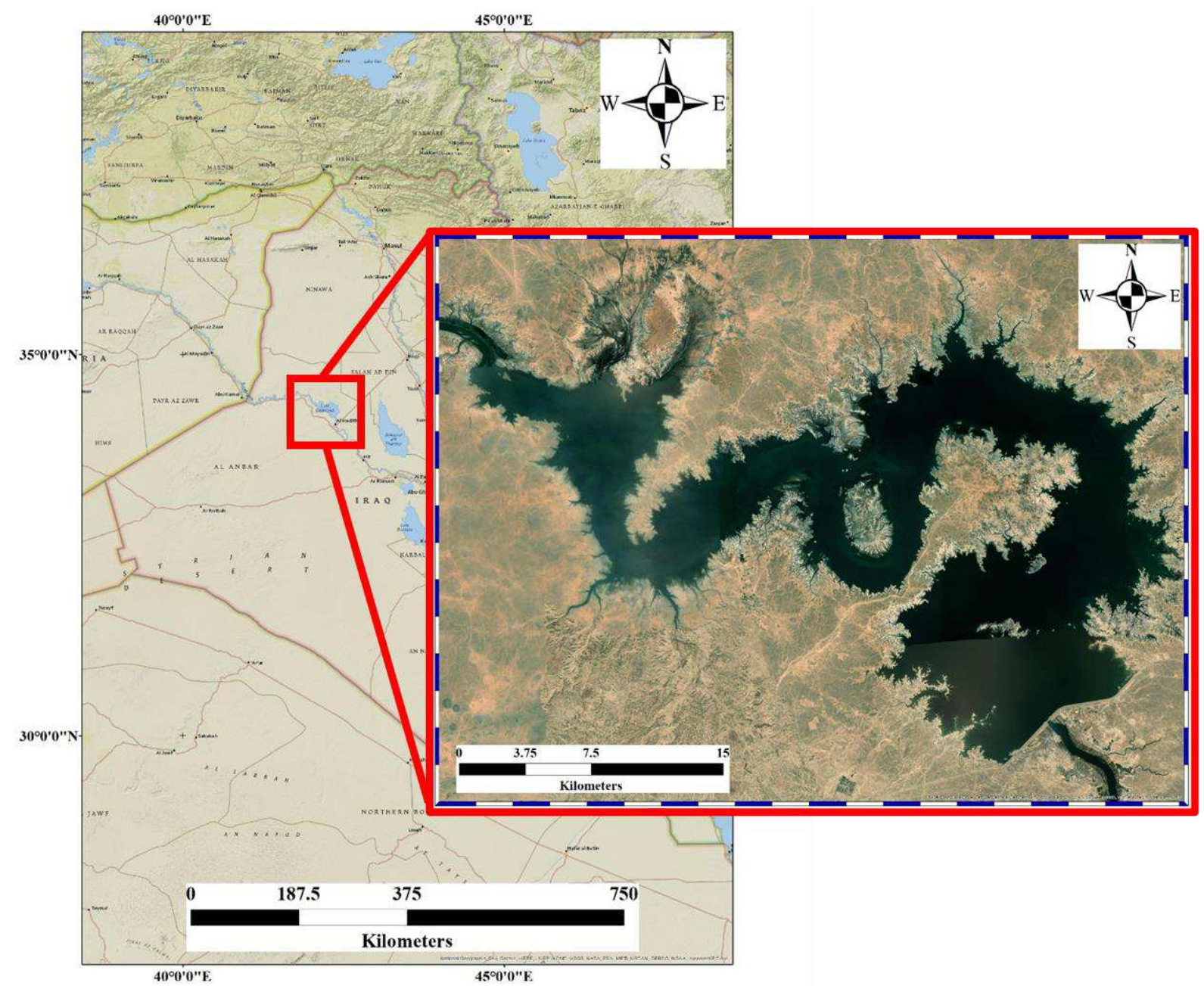

Figure 1. Geological map of the study area. (Modified from Sissakian and Fouad 2012).

The Euphrates River incises its course through the Miocene and Oligocene sediments in the sight of Wadi Hijlan springs between Haditha and al-Baghdadi sections CC1 and DD1 (Figure 2). The Euphrates and Anah Formations are considered major aquifers with semi-confined conditions and their water flow towards the discharge zone as springs. It is important to note that the waterbearing horizons of the Quaternary sediments are characterized by bank storage conditions and 
serve as a control in the relationship between the groundwater of aquifers and the surface waters of the Euphrates.

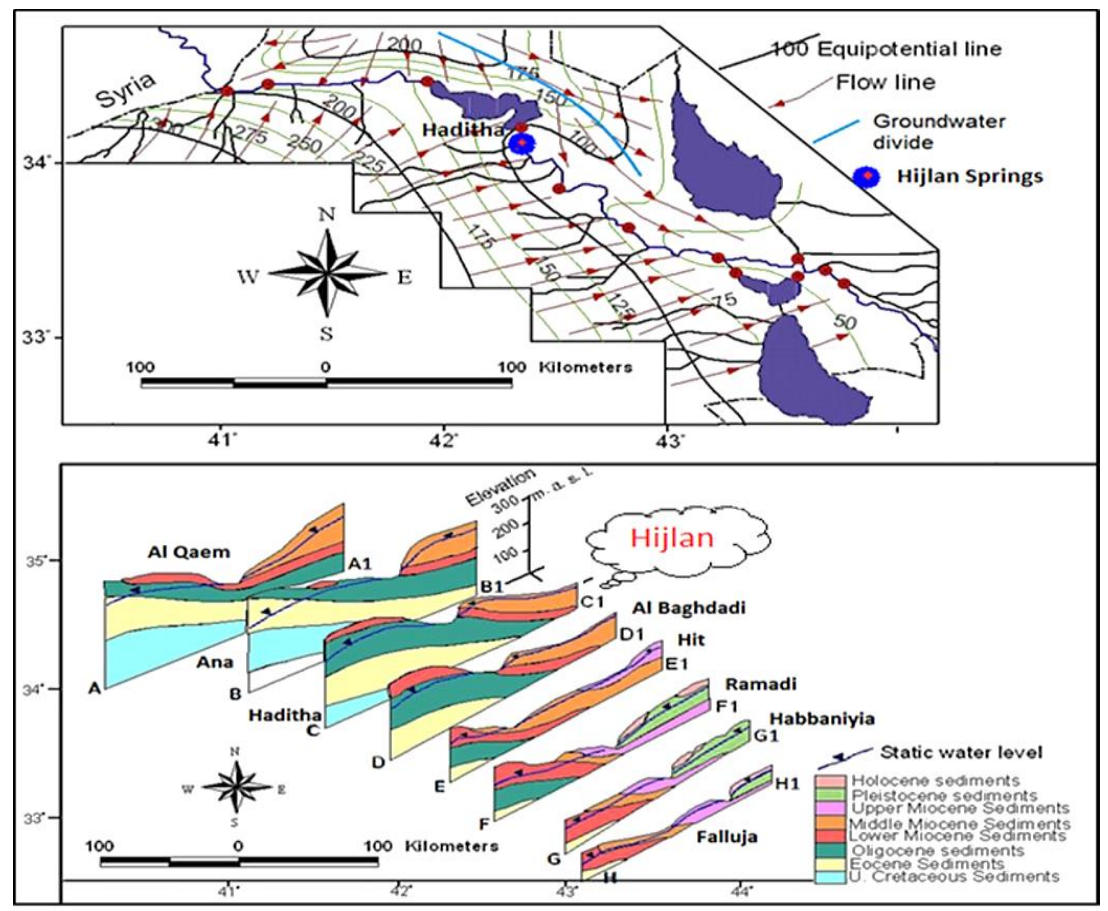

Fig. 2 Regional hydrogeologic sections and groundwater movement (Fayadh et al. 2016)

\section{Material and methodology}

\subsection{Study site description and sampling}

The equipment used in the hydrographic survey is Trimble Global Positioning System AG122 (GPS), Surfer software, and field notebook computer. GPS is used to determine exact locations (XY coordinates) on the earth's surface with approximately five to seven satellites locked in on the receiver at one time to ensure the highest level of accuracy. Surfer software was used to map the positions of the survey grids (UTM-zone-38) within the study area and during boat travels across the river surface. Thirty-five points were fixed for the sampling of water and the various measurements. Data collection was performed in Nov. (2019). Data generated from the monitoring procedure were used to produce an updated view of Hijlan Springs Creek. A total of 
286 different readings were recorded during the monitoring period (Tables S1-S2 in supplementary file).

Five water samples (S1, R1, M1, R2, and R3) were collected from Hijlan Creek and Euphrates (Figure 3) for the analysis of major cations, anions, minor anions, and trace elements. Six sites $(\mathrm{H} 1, \mathrm{H} 2, \mathrm{H} 3, \mathrm{H} 4, \mathrm{H} 5$, and H6) in the Hijlan (Table S1 in supplementary file) Creek were identified for the field analysis. Continuously, twenty-four field measurements numbered (D1D24) have been monitored along $250 \mathrm{~m}$ at the confluence of Hijlan Creek and the Euphrates to meet the research objectives (Table S2 in supplementary file).

Water samples were collected using polyethylene bottles according to the procedures of USEPA (2000). The samples were carefully sealed and tagged. The equipment used for sample collection was cleaned using deionized water (Barcelona et al., 1985; Shelton, 1994).

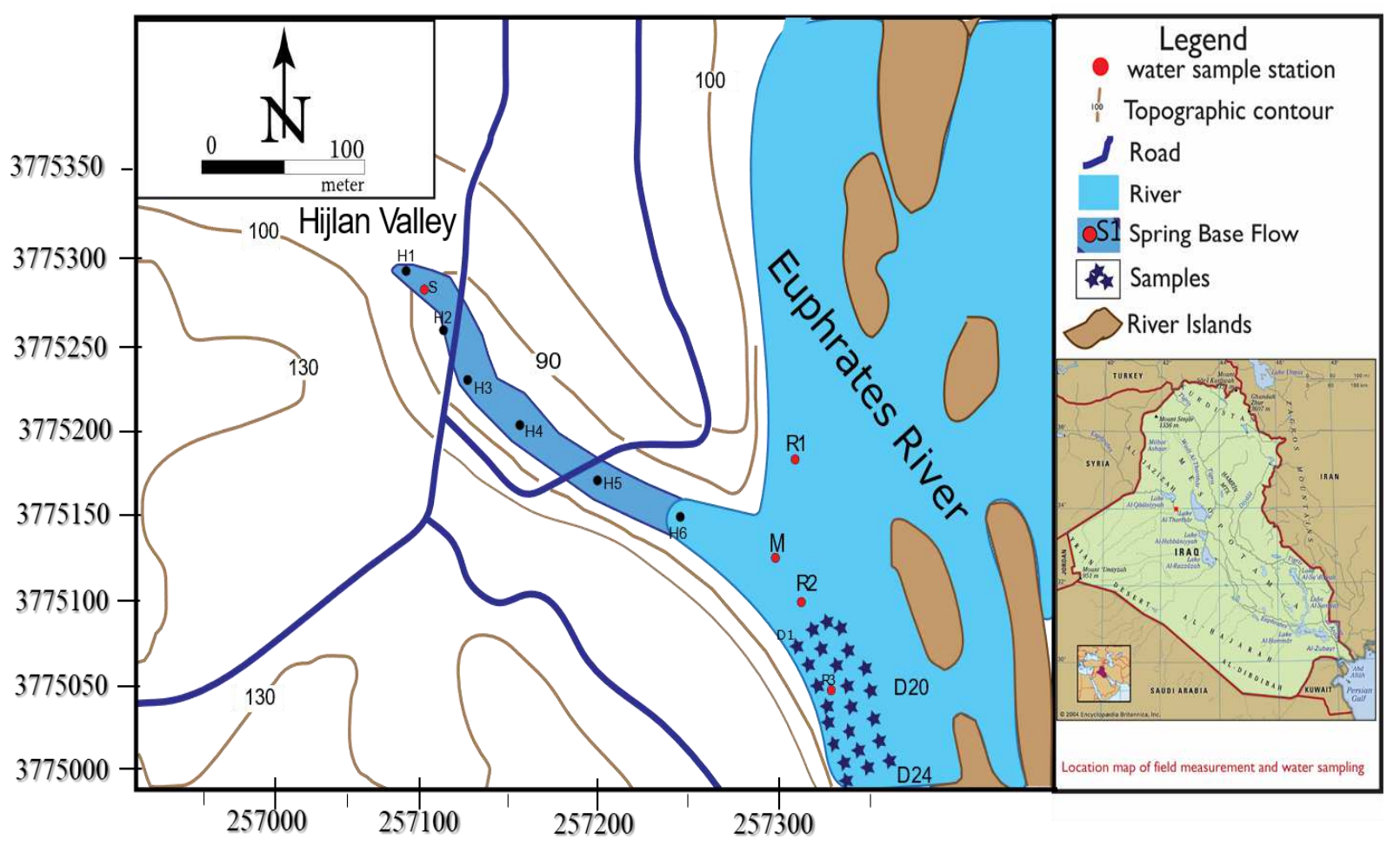

Figure 3. Location map of field measurement and water sampling 


\subsection{Physico-chemical and Heavy metal analysis}

The collected samples were transferred to a Quality control laboratory to analyze for all ions $\left(\mathrm{K}^{+}\right.$, $\mathrm{Na}^{+}, \mathrm{Ca}^{+2}, \mathrm{Mg}^{+2}, \mathrm{HCO}^{-3}, \mathrm{SO}_{4}^{-2}, \mathrm{Cl}^{-}, \mathrm{NO}^{-3}$ and $\mathrm{PO}_{4}^{-3}$ ), using the standard methods of the American Public Health Association (APHA, AWWA, WEF, 1995; APHA, 2012). Trace elements (Pb, Zn, $\mathrm{Cd}, \mathrm{Fe}$, and $\mathrm{Mn}$ ) were determined using Flame Cont. AA-7000 SHIMADZU (ROM Version, 1.03, S/N, A30945100295). The field analyzes (Temperature, pH, EC, TDS, and DO) were achieved using a portable multi-digit device (Aquaread AP-800-P). The $\mathrm{H}_{2} \mathrm{~S}$ dissolved in Hijlan Creek was determined by the addition of lead acetate to precipitate as lead sulfide for analysis (Robert, 1973). Turbidity values were expressed as nephelometric turbidity units (NTU) using a $\mathrm{HACH} 2100 \mathrm{P}$ field turbid-meter. The rank correlation coefficient of Spearman was used to determine the degree of the importance and the value of the relationship between studied variables (Helsel and Hirsch, 2002).

\subsection{Self-purification factor}

The model of space-time evolution of the concentration of dissolved oxygen (DO) and biological oxygen demand $\left(\mathrm{BOD}_{5}\right)$ towards downstream after contaminated discharges (Streeter and Phelps, 1925), was described as:

$\mathrm{D}_{\mathrm{t}}=\mathrm{Cs}-\mathrm{C}$

Where: $\mathrm{D}_{\mathrm{t}}$ denotes dissolved oxygen deficit, Cs represents saturated DO concentration (mg/l), and $\mathrm{C}$ stands for concentration of DO detected in DO plume.

\subsection{Contaminants Loads}

The discharge is directly calculated from velocity and cross-sectional area of the Creek using the formula (3):

$\mathrm{Q}=\frac{\mathrm{L}^{3}}{\mathrm{t}}=\mathrm{V}\left(\frac{\mathrm{L}}{\mathrm{T}}\right) * \mathrm{~A}\left(\mathrm{~L}^{2}\right)$ 
Calculating the discharge is crucial for the prediction of contaminant transport and load. Using the HOL procedure (Brikowski, 2011), an Impeller flow meter was utilized to determine average velocity across the entire Creek (Hijlan estuary) and right bank of the Euphrates river. The morphometric feature, velocity, and water discharge results are listed in Table2.

Table 1. Physico-chemical analysis of Euphrates River and Hijlan Creek water

\begin{tabular}{|c|c|c|c|c|c|}
\hline Variables & $\begin{array}{c}\text { S1 } \\
\text { Hijlan creek } \\
\text { X; } 257225 \\
\text { Y; } 3775130\end{array}$ & $\begin{array}{c}\mathrm{R} 1 \\
\text { Euphrates before mix } \\
\mathrm{X} ; 257286 \\
\mathrm{Y} ; 3775167\end{array}$ & $\begin{array}{c}\text { M1 } \\
\text { Mixing zone } \\
\text { X; } 257258 \\
\text { Y; } 3775118 \\
\end{array}$ & $\begin{array}{c}\mathrm{R} 2 \\
\text { Euphrates after mix } \\
\mathrm{X} ; 257275 \\
\mathrm{Y} ; 3775104 \\
\end{array}$ & $\begin{array}{c}\mathrm{R} 3 \\
\text { Euphrates after mix } \\
\text { X; } 257291 \\
\text { Y; } 3775052\end{array}$ \\
\hline $\mathrm{pH}$ & 7.0 & 7.5 & 7.7 & 7.37 & 7.4 \\
\hline $\mathrm{EC} \mu \mathrm{S} / \mathrm{cm}$ & 5076 & 985 & 1281 & 1350 & 1277 \\
\hline Temp ${ }^{\circ} \mathrm{C}$ & 25.2 & 21.5 & 21.2 & 21.4 & 22 \\
\hline Turb. NTU & 1.02 & 0.7 & 0.38 & 0.84 & 1.02 \\
\hline TSS mg/l & 4 & 2 & 2 & 1 & 4 \\
\hline $\mathrm{H}_{\mathrm{T}} \mathrm{mg} / \mathrm{l}$ & 1694 & 343 & 530 & 520 & 635 \\
\hline TDS mg/l & 3220 & 673 & 1000 & 923 & 730 \\
\hline $\mathrm{K}^{+} \mathrm{mg} / \mathrm{l}$ & 36 & 2.5 & 33 & 3.2 & 8.5 \\
\hline $\mathrm{Na}^{+} \mathrm{mg} / \mathrm{l}$ & 556 & 76 & 105 & 119 & 190 \\
\hline $\mathrm{Mg}^{++} \mathrm{mg} / \mathrm{l}$ & 207 & 37 & 74 & 65 & 80 \\
\hline $\mathrm{Ca}^{++} \mathrm{mg} / \mathrm{l}$ & 338 & 77 & 90 & 101 & 123 \\
\hline $\mathrm{Cl}^{-} \mathrm{mg} / \mathrm{l}$ & 1330 & 152 & 190 & 230 & 403 \\
\hline $\mathrm{SO}_{4}^{--} \mathrm{mg} / \mathrm{l}$ & 555 & 157 & 377 & 253 & 321 \\
\hline $\mathrm{HCO}_{3}{ }^{-} \mathrm{mg} / \mathrm{l}$ & 199 & 135 & 130 & 150 & 133 \\
\hline $\mathrm{CO}_{3}^{-2} \mathrm{mg} / 1$ & 0.4 & 0.2 & 0.3 & 0.2 & 0.1 \\
\hline $\mathrm{NO}_{3}{ }^{-} \mathrm{mg} / \mathrm{l}$ & 1.0 & 0.2 & 1 & 2 & 1 \\
\hline $\mathrm{PO}_{4}^{-3} \mathrm{mg} / \mathrm{l}$ & $<0.1$ & $<0.1$ & $<0.1$ & $<0.1$ & $<0.1$ \\
\hline DO mg/l & 3.2 & 7.8 & 5 & 7.1 & 7.7 \\
\hline $\mathrm{BOD}_{5} \mathrm{mg} / \mathrm{l}$ & 5.5 & 0.4 & 0.8 & 0.6 & 0.2 \\
\hline $\mathrm{Cu} \mathrm{mg} / \mathrm{l}$ & 0.0041 & 0 & 0.0135 & 0 & 0 \\
\hline Co mg/l & 0 & 0.0079 & 0 & 0 & 0.166 \\
\hline Mn mg/l & 0.0068 & 0.02 & 0 & 0.029 & 0.02 \\
\hline $\mathrm{Cd} \mathrm{mg/l}$ & 0.009 & 0 & 0.0031 & 0.0055 & 0.0047 \\
\hline $\mathrm{Fe}, \mathrm{Zn}, \mathrm{Pb} \mathrm{mg} / \mathrm{l}$ & 0 & 0 & 0 & 0 & 0 \\
\hline
\end{tabular}

Table 2. Water velocity and discharge (Euphrates and Hijlan Springs Creek)

\begin{tabular}{cccccccc}
\hline Station ID & Test No. & $\begin{array}{c}\text { Velocity } \\
\mathrm{m} / \mathrm{sec}\end{array}$ & $\begin{array}{c}\text { Depth } \\
\mathrm{m}\end{array}$ & $\begin{array}{c}\text { Width } \\
\mathrm{m}\end{array}$ & $\begin{array}{c}\text { Cr. Sec. Area } \\
\mathrm{m}^{2}\end{array}$ & $\begin{array}{c}\text { Discharge } \\
\mathrm{m}^{3} / \mathrm{sec}\end{array}$ & Remark \\
\hline \multirow{3}{*}{ Hijlan } & 1 & 0.277 & 0.49 & 21 & 10.29 & 2.85 & \\
& 2 & 0.357 & 0.55 & 21 & 11.55 & 4.12 & X; 0257085 \\
& 3 & 0.294 & 0.65 & 21 & 13.65 & 4.01 & Y; 3775257 \\
\cline { 2 - 7 } & Average & 0.31 & 0.563 & 21 & 11.83 & 3.66 & \\
\hline \multirow{2}{*}{ Euphrates } & 1 & 0.192 & 2 & 135 & 270 & 51.84 & \\
River & 2 & 0.238 & 2.5 & 135 & 337.5 & 80.33 & X; 0257089 \\
(Right & 3 & 0.185 & 2.6 & 135 & 351 & 64.93 & Y; 3775253 \\
Island) & Average & 0.21 & 2.37 & 135 & 319.5 & 66.0 & \\
\hline
\end{tabular}




\section{Results and discussion}

\subsection{Contamination Plume Behavior and Characterization}

A statistical comparison of the concentrations of ions versus total dissolved solids and the physicochemical components against $\mathrm{DO}$ and $\mathrm{H}_{2} \mathrm{~S}$ concentration was performed, according to the Spearman correlation coefficient equation (4):

$\left.\left(r_{s}\right)=1-6 \sum \llbracket \frac{d_{i}^{2}}{n\left(n^{2}-1\right)}\right)$

Where $d_{i}=x_{i}-y_{i}$ represents the difference in ranks for the $i$-th individual and $n$ denotes the number of individuals (Helsel and Hirsch, 2002).

Positive associations of ranks are observed between TDS and $\mathrm{H}_{2} \mathrm{~S}$ for all parameters, except for Co and Mn (Table 3) due to the impact of $\mathrm{H}_{2} \mathrm{~S}$ on their concentration via precipitation mechanism. Both Co and Mn are confirmed by a linear positive relationship to the DO concentration. The emergence of a close correlation between the measured physicochemical variables is a contamination indicator and it trends the active effect of the spring water on surface water.

Table 3. Statistical correlations according to the results of Spearman Rank Coefficient

\begin{tabular}{|c|c|c|c|c|c|}
\hline Variable & $\begin{array}{l}\text { Spearman Rank } \\
\text { Coefficient }\left(\mathrm{r}_{\mathrm{s}}\right)\end{array}$ & Variable & $\begin{array}{l}\text { Spearman Rank } \\
\text { Coefficient }\left(\mathrm{r}_{\mathrm{s}}\right)\end{array}$ & Variable & $\begin{array}{l}\text { Spearman Rank } \\
\text { Coefficient } r_{\mathrm{s}}\end{array}$ \\
\hline TDS mg/l & 1.0 & $\mathrm{DO} \mathrm{mg} / \mathrm{l}$ & 1.0 & $\mathrm{H}_{2} \mathrm{~S} \mathrm{mg/l}$ & 1.0 \\
\hline $\mathrm{K} \mathrm{mg} / \mathrm{l}$ & 0.9 & Temp ${ }^{\circ} \mathrm{C}$ & -0.6 & Temp ${ }^{\circ} \mathrm{C}$ & 0.5 \\
\hline $\mathrm{Na} \mathrm{mg} / \mathrm{l}$ & 0.9 & $\mathrm{pH}$ & -0.525 & $\mathrm{pH}$ & 0.875 \\
\hline $\mathrm{Mg} \mathrm{mg/l}$ & 1 & Turb. NTU & -0.125 & Turb. NTU & 0.175 \\
\hline Ca mg/l & 0.9 & $\mathrm{BOD}_{5} \mathrm{mg} / \mathrm{l}$ & -0.9 & $\mathrm{BOD}_{5} \mathrm{mg} / \mathrm{l}$ & 0.9 \\
\hline $\mathrm{Cl} \mathrm{mg/l}$ & 0.9 & $\mathrm{H}_{2} \mathrm{~S} \mathrm{mg} / \mathrm{l}$ & -0.7 & DO mg/l & -0.7 \\
\hline $\mathrm{SO}_{4} \mathrm{mg} / \mathrm{l}$ & 0.9 & $\mathrm{NO}_{3} \mathrm{mg} / \mathrm{l}$ & -0.3 & $\mathrm{NO}_{3}{ }^{-} \mathrm{mg} / \mathrm{l}$ & 0.2 \\
\hline $\mathrm{HCO}_{3} \mathrm{mg} / \mathrm{l}$ & 0.2 & $\mathrm{PO}_{4} \mathrm{mg} / \mathrm{l}$ & 0.5 & $\mathrm{PO}_{4} \mathrm{mg} / \mathrm{l}$ & 0.6 \\
\hline $\mathrm{Cu} \mathrm{mg} / \mathrm{l}$ & 0.5 & $\mathrm{Cu} \mathrm{mg} / \mathrm{l}$ & -0.6 & $\mathrm{Cu} \mathrm{mg} / \mathrm{l}$ & 0.9 \\
\hline Co $\mathrm{mg} / \mathrm{l}$ & 0 & Co $\mathrm{mg} / \mathrm{l}$ & 0.8 & Co $\mathrm{mg} / \mathrm{l}$ & -0.3 \\
\hline $\mathrm{Mn} \mathrm{mg} / \mathrm{l}$ & -0.425 & Mn mg/l & 0.575 & $\mathrm{Mn} \mathrm{mg} / \mathrm{l}$ & -0.575 \\
\hline $\mathrm{Cd} \mathrm{mg} / \mathrm{l}$ & 0.7 & $\mathrm{Cd} \mathrm{mg} / \mathrm{l}$ & -0.7 & $\mathrm{Cd} \mathrm{mg/l}$ & 0.5 \\
\hline
\end{tabular}




\subsection{PH, Dissolved oxygen, Biological oxygen demand, and Nitrate Plume}

Physico-chemical parameters, such as $\mathrm{pH}, \mathrm{BOD}_{5}, \mathrm{DO}$, dissolved ions and metals, etc., were used as a dilution indicator to produce a Geo-referenced contamination plume for minero-medicinal spring water discharge. The $\mathrm{pH}$ is influenced by the dissolved species and various chemical reactions that differentially occur through the water column. The major reactions that affect the magnitude of $\mathrm{pH}$ are reactions that occur in aerobic/oxic conditions (Wetzel, 1983; Morel and Hering, 1993). Figure 4 shows the measured $\mathrm{pH}$ values increase from 7 to 7.2 from springs locations towards downstream, under oxidation reactions and limited by reducing reactions (Stumm and Morgan, 1981). A plume with $\mathrm{pH}$ of 7.4 emerged in the confluence zone, which can be attributed to the mixing of water of the Euphrates River ( $\mathrm{pH}$ range of 7.6 - 7.8) with that of Hijlan Creek ( $\mathrm{pH}$ range of 7.0 - 7.2). A drop in $\mathrm{pH}$ is detected upstream (Figure 5, pH). The DO dynamics of Hijlan Creek is not typical for a natural stream with storm runoff. The DO concentration range of 2 to $2.9 \mathrm{mg} / \mathrm{l}$ is attributed to the groundwater origin (oxygen consumption by bacterial decomposition). Afterward, the gradual increase in DO concentration to $3.8 \mathrm{mg} / \mathrm{l}$ towards the confluence zone (Figure 4) is due to the external contribution of oxygen from the solubilization of atmospheric oxygen.

The rate of reaeration is assumed to be proportional to the difference between the saturation and observed concentrations of DO (mg/l). The reaeration rate coefficient $\mathrm{K}_{2}$ (1/time) is a sensitive parameter that can be calculated using the following equations (5) (Van Pagee, 1978; Delvigne, 1980):

$K_{2}=\left\{\frac{\left.\{0.065 \text { (WindVelocity })^{2}+3.86\left[\frac{\text { water velocity }}{\text { water depth }}\right]^{0.5}\right\}}{\text { Water depth }}\right\}$ 
$\begin{array}{ll}K_{2}=\left\{\frac{\left\{0.065(1)^{2}+3.86\left[\frac{0.31}{0.563}\right]^{0.5}\right\}}{0.563}\right\}=\left\{5.32 \mathrm{sec}^{-1}\right\} & \text { Hijlan Creek } \\ K_{2}=\left\{\frac{\left\{0.065(1)^{2}+3.86\left[\frac{0.21}{2.37}\right]^{0.5}\right\}}{2.37}\right\}=\left\{0.51 \mathrm{sec}^{-1}\right\} & \text { Euphrates River }\end{array}$
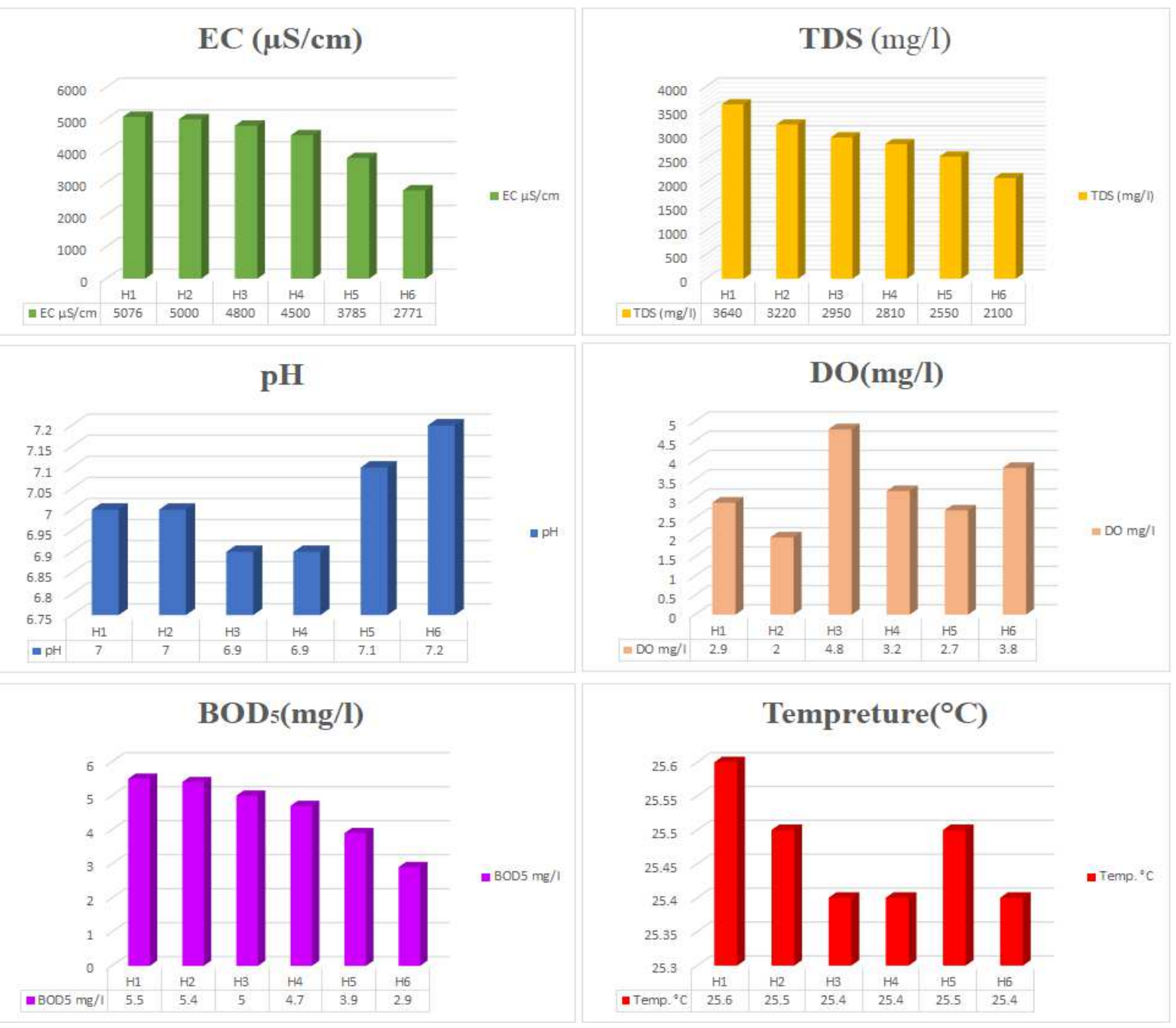

Figure 4. Hijlan water Physico-chemical fluctuations

The onset of anoxic conditions is proximately followed by DO mixing zone (Figure 5, DO), initiated by the water of Euphrates main body, which is defined as three eddies of DO plume ranging from 4.5 to $6.5 \mathrm{mg} / \mathrm{L}$. At the end portion of the DO plume, Euphrates water was re- 
oxygenated by an aeration rate $\left(\mathrm{K}_{2}\right)$ of $0.51\left(\mathrm{sec}^{-1}\right)$ until the DO concentration reached $7.5 \mathrm{mg} / \mathrm{l}$. The reverse phenomenon of $\mathrm{BOD}_{5}$ concentration occurs in Hijlan Creek, as the concentration decreases from $5.5 \mathrm{mg} / \mathrm{l}$ to $1.8 \mathrm{mg} / \mathrm{l}$ towards the mixing zone (Figure 4), due to air oxygenation in the direction of streamflow. This is followed by mixing-dilution in the Euphrates water of less than $1 \mathrm{mg} / \mathrm{l}$ of $\mathrm{BOD}_{5}$ concentration (Figure 5, $\mathrm{BOD}_{5}$ ). Comparison of the measured $\mathrm{BOD}_{5}$ values with the water quality standard indicates the water in the monitored zones is fair for the purposes of aquatic life but not recommended for drinking.

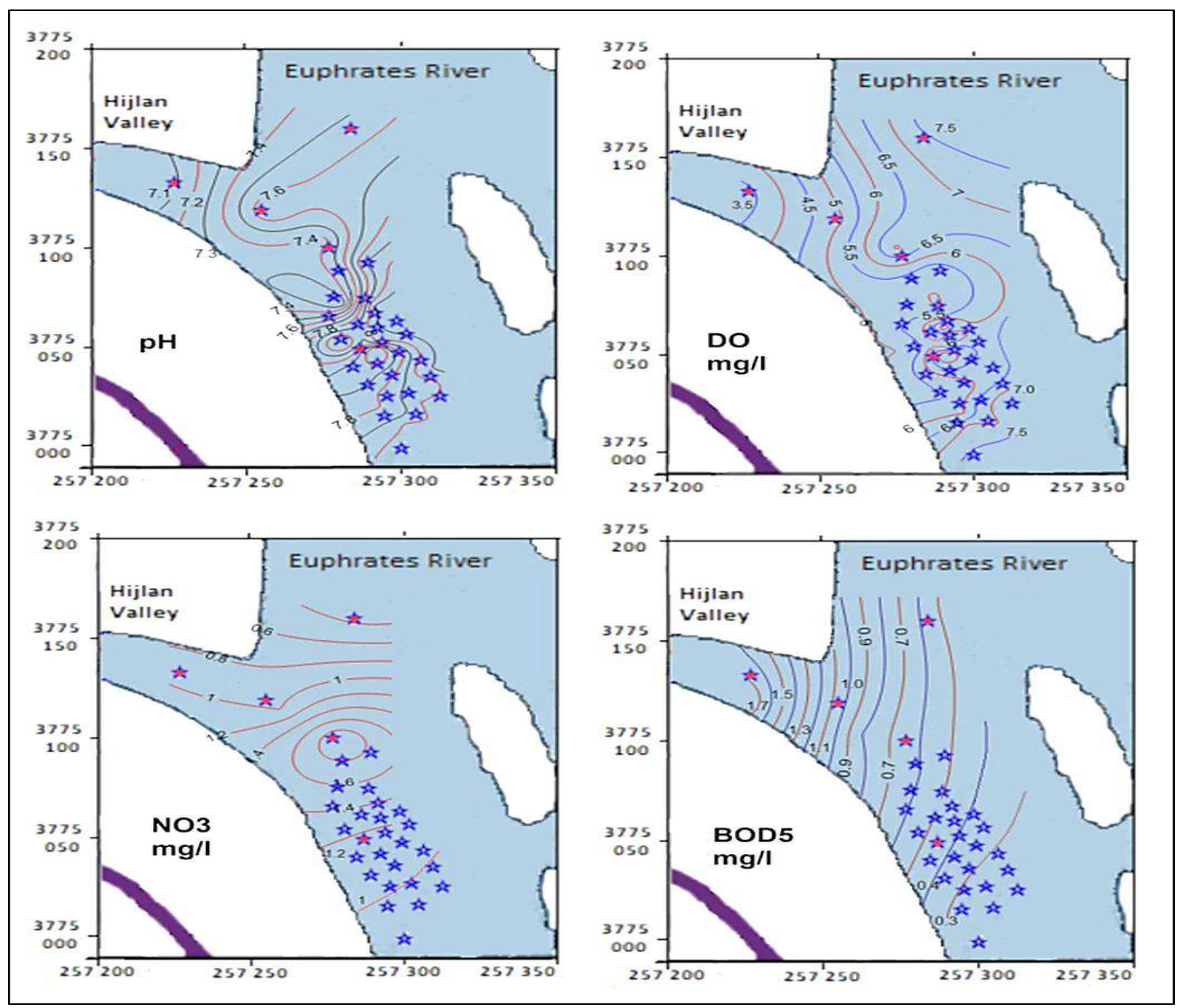

Figure 5. Spatial distribution map of $\mathrm{pH}, \mathrm{DO}, \mathrm{BOD}_{5}$, and $\mathrm{NO}$

The observed concentration of nitrate $(0.2$ to $2 \mathrm{mg} / \mathrm{l})$ in the zone of Hijlan inflow and Euphrates River is less than the permissible limit for drinking (Figure 5, $\mathrm{NO}_{3}$ ). No observable phenomena 
of spatial mixing and dilution were detected because of alternative Redox reactions (water column oxygenation), bacterial nitrification to nitrate, and/or denitrification to atmospheric as $\mathrm{N}_{2}$ is dependent on the amount of organic matter (Stumm and Morgan, 1981). However, the phosphate concentrations were not measured at or above the detected analysis limit of $0.05 \mathrm{mg} / \mathrm{l}$.

\subsection{Self-purification factor}

Dissolved oxygen deficit, saturated DO concentration, and concentration of DO (downstream) detected in DO plume (Figure 5 DO) were used to investigate the self-purification factor depending on equation (2). Therefore, the deoxygenation coefficient and the reaeration coefficient must be calculated in order to obtain a self-purification factor as shown in equations 6,7 , and 8 .

$$
\frac{\delta D_{t}}{\delta t}=k_{1} b_{t}-k_{2} D_{t}
$$

Where: $b_{t}$ denotes ultimate first stage BOD $_{5}$ of the mix at the point of discharge $(1.1 \mathrm{mg} / \mathrm{l})$ detected in $\mathrm{BOD}_{5}$ plume (Figure $\left.5 \mathrm{BOD}_{5}\right), \mathrm{k}_{1}$ deoxygenation coefficient $\left(\mathrm{sec}^{-1}\right), \mathrm{k}_{2}$ reaeration coefficient $\left(\sec ^{-1}\right), \mathrm{t}$; time (sec).

$$
\text { time }(\mathrm{sec})=\frac{\text { distance of mixing }(\mathrm{m})}{\text { water velocity }\left(\frac{\mathrm{m}}{\mathrm{sec}}\right)}=\frac{50}{2.37}=21 \mathrm{sec}
$$

The model uses the coefficient $\mathrm{k}_{1}$, which is dependent on the contaminant characteristics while the re-aeration coefficient $\mathrm{k}_{2}$ is dependent on water temperature, velocity, and depth of the river. The reaeration coefficient $\left(\mathrm{k}_{2}\right)$ value is $0.51 \mathrm{sec}^{-1}$ as previously calculated. From equation (6) $\left(\mathrm{k}_{1}\right)$ is:

$$
\begin{aligned}
& k_{1}=\frac{\left[\left(\frac{\delta D_{t}}{\delta t}\right)+k_{2}\right]}{b_{t}} \\
& \mathrm{k}_{1}=\frac{\left[\left(\frac{9-5}{21}\right)+0.51 * 4\right]}{1.1}=2.03 \mathrm{sec}^{-1}
\end{aligned}
$$


After integration, Equation 6 (Waite et al., 1977; Kiely, 1998; Omole and Longe, 2012) gives: (f) $=$ Self-purification factor, which is defined by equation (8):

$$
\mathrm{f}=\frac{\mathrm{k}_{2}}{\mathrm{k}_{1}}
$$

$\frac{0.51}{2.03}=25 \%$

The ability of the river water self-purification is a significant measure of river quality. When the contaminants in the waterways are outside the purification capacity of the river, they create significant pollution of the water system (Tien et al., 2019). The result of self-purification indicated that the Euphrates river has a good ability to purify the pollutants coming from the Hijlan springs due to the velocity of the water flow in the study area. In addition, the algae in the Euphrates river help water to recover the rate of dissolved oxygen values that caused selfpurification.

\subsection{Temperature and Turbidity Plume}

Water temperature is frequently being used as a "tracer" to indicate the dilution and spatial distribution of other important water quality parameters that may occur within a mixing zone if the water temperature differential occurs. Domestic and/or wastewater is often warmer than the ambient environment. Therefore, thermal detection could be used to monitor the effects of sewage discharges on recreational areas. The water temperature of Hijlan Creek is $25.6^{\circ} \mathrm{C}$ (hypothermal water), which decreases gradually to $24.6^{\circ} \mathrm{C}$ with the flow direction (Figure 4) as it is affected by air temperature $\left(18^{\circ} \mathrm{C}\right)$. Here and in the last 50 meters of Hijlan valley, a mixed zone appears as shown in Figure 6 (Temp). This zone was characterized by a water temperature range of $22.6^{\circ} \mathrm{C}$ to $24.6^{\circ} \mathrm{C}$, which is formed due to water mixing between Hijlan Creek $\left(>24.6{ }^{\circ} \mathrm{C}\right)$ and the main body of Euphrates River $\left(<22.2{ }^{\circ} \mathrm{C}\right)$. In the downstream direction, multi-temperature plumes of $24.6^{\circ} \mathrm{C}$ are clearly observed near the right shoreline of 
the Euphrates River. The recovery zone of tepid water with a temperature of $<23.4{ }^{\circ} \mathrm{C}$ was detected in the last monitored water points.

Turbidity is a water clarity measure that indicates the amount of debris in the water, which limits the passage of light. It is expressed by the nephelometric unit (NTU). Light scattering turbidity measurements were taken at depths ranging from 10 to $35 \mathrm{~cm}$. The lowest turbidity value of less than 0.7 NTU was recorded during low wind speed in the confluence zone, which gradually increased downstream reaching 1.02 NTU (Figure 7, Tur). Comparison of the turbidity values with the water quality standard indicates the healthy limit for aquatic life. Normally, well-run municipal supplies have less than 0.5 NTU before disinfection and should be regulated to an average of 0.2 NTU or less.

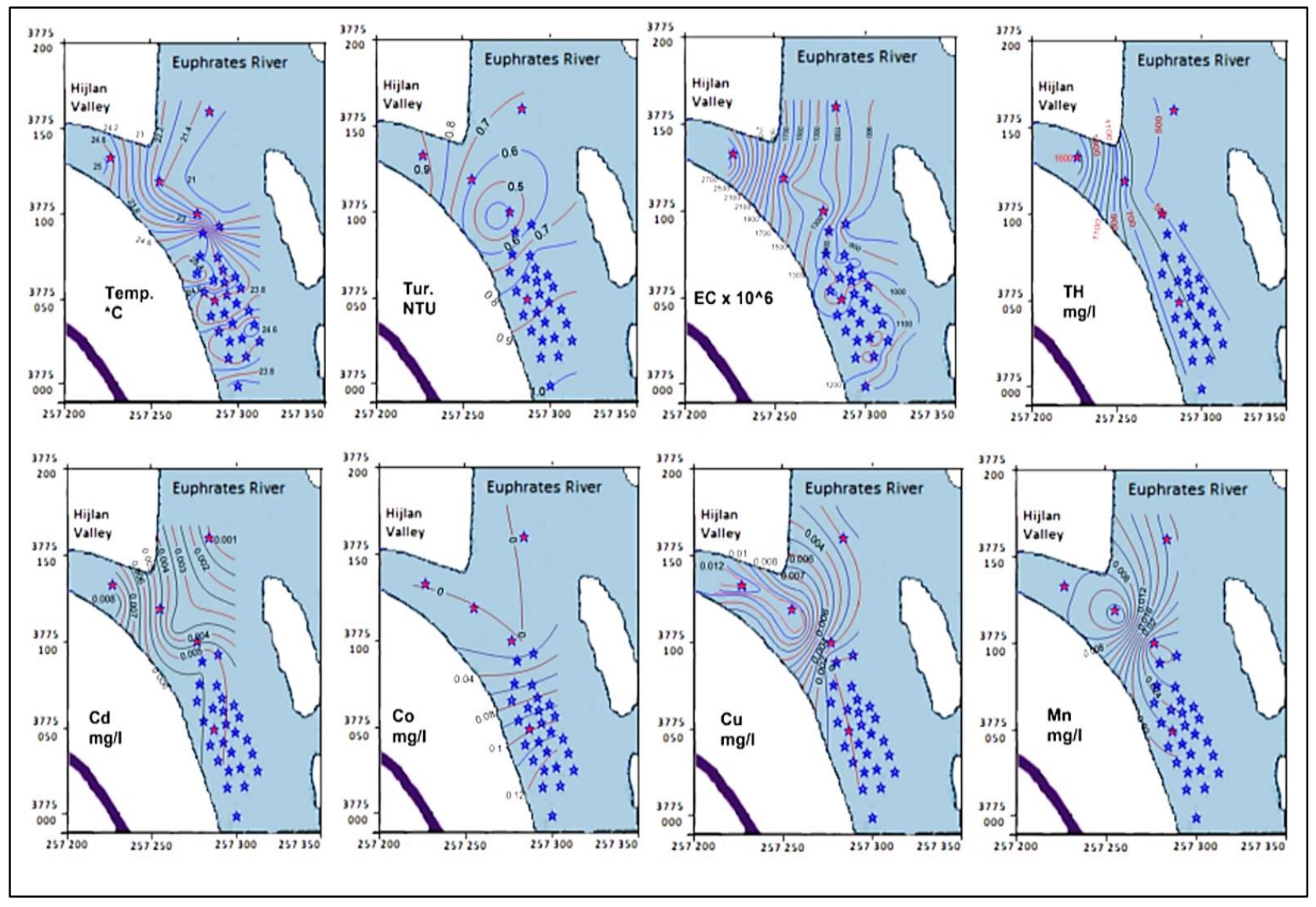

Figure 6. Spatial distribution map of Temp, Tur, EC, TH, Cd, Co, Cu and Mn 


\subsection{Electrical conductivity (EC) and Total Dissolved Solids (TDS) Plumes}

The mixing of the Euphrates River with Hijlan Creek water, which possesses different electrical conductivities, can also exhibit TDS differentiation. The electrical conductivity values ranged from 2771 to $5076 \mu \mathrm{S} / \mathrm{cm}$, while the TDS values vary between 2100 and $3640 \mathrm{mg} / \mathrm{l}$, within a Hijlan stream (Figure 4). Under a condition of dilution gradient of $11.2 \mu \mathrm{S} / \mathrm{cm}$ per meter and 10 $\mathrm{mg} / \mathrm{l}$ per meter, the EC and TDS exhibit a range of $800-2700 \mu \mathrm{S} / \mathrm{cm}$ and $600-2100 \mathrm{mg} / \mathrm{l}$, respectively (Figure 6, EC and Figure 7, TDS). The results show a direct relationship between the TDS plume and conductivity measures. Similar to conductivity, higher TDS concentrations were measured at the shoreline of the Euphrates River, where the shallow depth of the confluence zone causes water to mix vertically with rapid linear dilution. The confluence zone also exhibits full lateral dilution towards downstream sectors, depending on river bathymetry, water velocity, and discharge, to form the plume boundary interaction.

The total hardness is a measure of the calcium $\left(\mathrm{Ca}^{2+}\right)$ and magnesium $\left(\mathrm{Mg}^{2+}\right)$ content of water and is mainly used to assess the quality of water supply as an industrial water source. Variations in hardness reflect changes in dissolved water constituents, induced by water chemistry changes (Langmuir 1997). The water that flows from Hijlan Creek exhibits a higher hardness value (very hard water) than river water at the upstream site. A decrease in hardness concentration caused by discharge dilution was visibly observed at the site of mixing, indicated by the decline in TDS value from $1600 \mathrm{mg} / \mathrm{l}$ to 500 - $600 \mathrm{mg} / \mathrm{l}$ (Figure 6, TH).

The mixing-dilution gradient of cationic water chemistry, such as $\mathrm{K}, \mathrm{Na}, \mathrm{Mg}$, and $\mathrm{Ca}$ within the beginning part of the contaminated plume was $0.8,0.66,0.83$, and $0.5 \mathrm{ppm} / \mathrm{meter}$ respectively with an average of $0.69 \mathrm{ppm} / \mathrm{meter}$ (Figure 7). The identified enrichment gradient relative to the river upstream in the mid and the tail of the plume reached $0.11,1.06,0.26$, and $0.27 \mathrm{ppm} / \mathrm{meter}$ with an average of $0.43 \mathrm{ppm} / \mathrm{meter}$. The difference between concentration dilution mechanisms in the onset of mixing, which is higher than the enrichment mechanism, is attributed to the water 
velocity and discharge differences, where the concentrations of the chemical ions are highly influenced by river flow dilution (Pasquini and Sacchi, 2012).

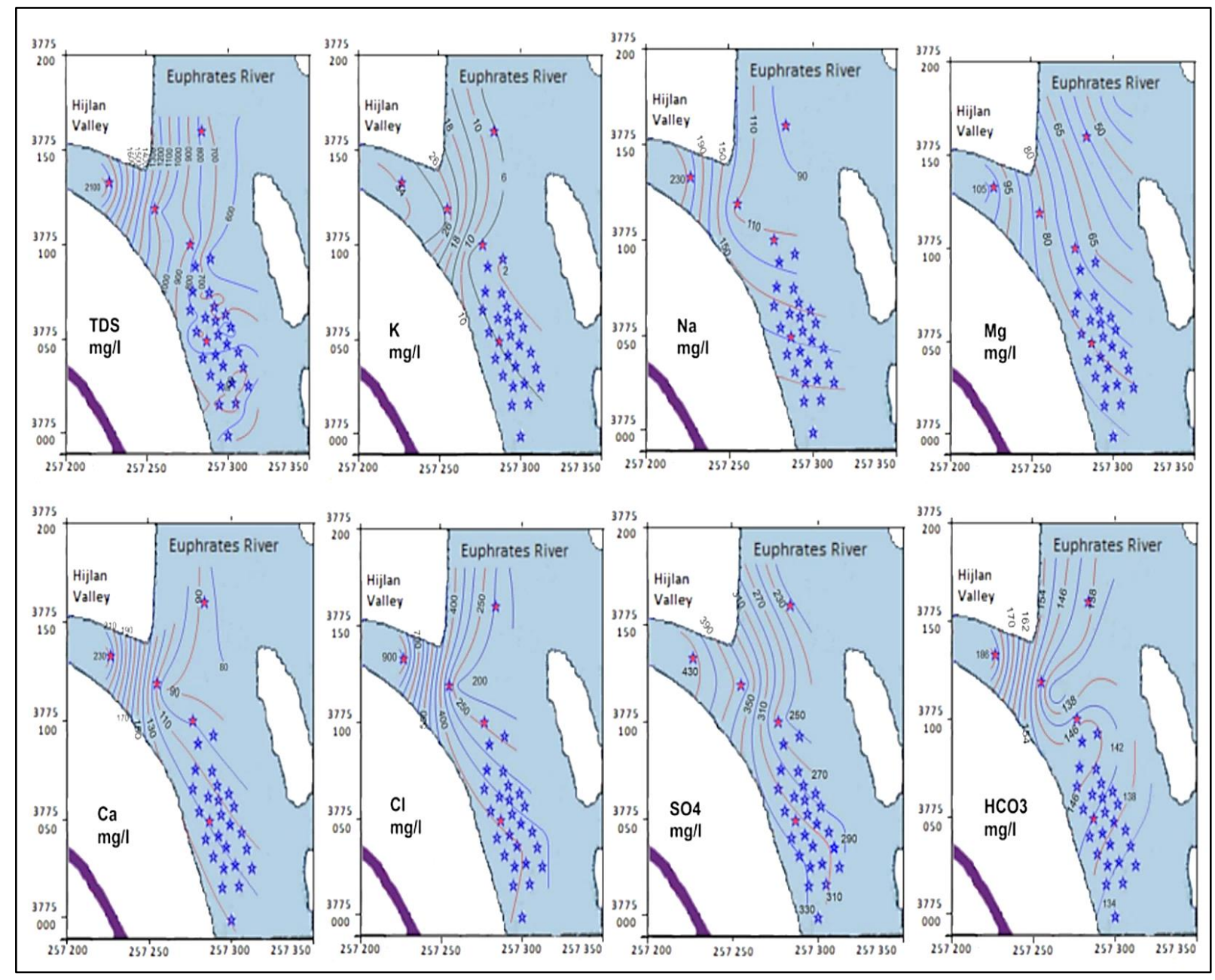

Figure 7. Spatial distribution map of TDS, $\mathrm{K}, \mathrm{Na}, \mathrm{Mg}, \mathrm{Ca}, \mathrm{Cl}, \mathrm{SO}_{4}$, and $\mathrm{HCO}_{3}$

The iso-concentration contour maps of the anionic water chemistry $\left(\mathrm{Cl}, \mathrm{SO}_{4}\right.$, and $\left.\mathrm{HCO}_{3}\right)$ (Figure 7) closely follow the spatial distribution TDS content (positive relation) and $\mathrm{pH}$ values (an inverse relationship). This is likely due to alternate impacts of dilution and oxygenation mechanisms. The mixed water is slightly alkaline due to buffer bicarbonate (concentration range of 134 to 186 $\mathrm{mg} / \mathrm{l}$ ), caused by changes in water chemistry. Despite the low concentration of trace elements of copper and cadmium, their distribution is similar to that of dissolved ions, while no effect of spring water on the Euphrates was observed for manganese (Mn) and cobalt (Co). The changes in their concentrations are attributed to the conditions of river water movement and may be 
consistent with re-suspension of sediments from the bottom and solubilization of $\mathrm{Mn}$ and Co elements present in the sediment.

\subsection{Contaminants Loads and Mixing Mechanism}

The Euphrates has been subjected to chemical hazards contamination resulting from springs outflow. Thus, it is important to assess the degradation degree of the river and its effects of contamination on human health and fishery survival. The daily load discharge of contaminants to the Euphrates was calculated using a standard flux-based algorithm according to the metrics of instantaneous discharge and concentration (Little and Marsh, 2005; Johnes, 2007), where:

$$
\begin{aligned}
& \text { Load Discharge }\left(\frac{\text { ton }}{\text { day }}\right) \\
& \qquad=\text { Water discharge }(Q)\left(\frac{m 3}{\text { day }}\right) \times \text { Concentration }(C)\left(\frac{m g}{L}\right) \times 10-6
\end{aligned}
$$

The daily loads of contaminants observed during the monitoring phase are listed in Table 4 . The concentrations of anions and cations account for $<65 \%$ and $35 \%$ of the total contaminants, respectively, with very small percentages of heavy metals. The concentration of $\mathrm{Cl}^{-}$is used to calculate the mixing ratio because it is less affected by chemical reactions in the aqueous environment (Langmuir, 1997). The rate of mixing of Hijlan Creek with Euphrates water in the confluence zone was calculated using the concentration of chloride ions (Mullaney et al., 2009), as shown in the following equation (10):

$\mathrm{R} \%=\left\{\frac{\left[\mathrm{Cl}_{\text {downstream }}\right]-\left[\mathrm{Cl}_{\text {upstream }}\right]}{\left[\mathrm{Cl}_{\text {springs Creek }}\right]-[\mathrm{Cl} \text { _downstream }]}\right\} \times 100$

Where: R\% signifies the proportion of chloride concentration between Euphrates River and Hijlan Springs, $\mathrm{Cl}_{\text {downstream }}$ denotes chloride concentration of Euphrates water after the confluence zone,

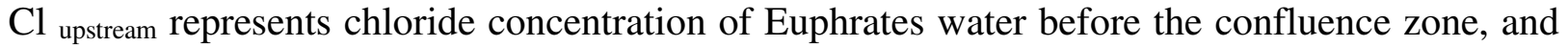
$\mathrm{Cl}_{\text {springs }}$ Creek stands for the chloride concentration of Hijlan Creek. 
$R \%=\left\{\frac{(230 m g / L-152 m g / L)}{(1330 m g / L-230 m g / L)}\right\} \times 100=7.1 \%$.

The results imply that $7.1 \%$ of $\mathrm{Cl}^{-}$in the confluence zone is derived from the Euphrates upstream and $92.9 \%$ comes from Hijlan Springs Creek with no storm runoff. The multi-source water condition is attributed to enrichment caused by direct brackish disposal water. These percentile results were calculated under the following conditions:

1- Hijlan Creek water discharged into Euphrates River was 316,224 m³/day, with 420 tons/day and 1020 tons/day for chloride and TDS load discharge, respectively.

2- The upstream water discharge during the period of observation was 5.7 x $106 \mathrm{~m} 3$ /day, with 867 ton/day and 3836 ton/day for $\mathrm{Cl}$ and TDS load discharge, respectively, passes through the Euphrates River in the upstream sector.

3- The downstream discharge during the period of observation was $6.02 \times 106 \mathrm{~m} 3$ /day, with 1287 tons/day and 4856 tons/day for $\mathrm{Cl}$ and TDS load discharge, respectively passes through the upstream river sector.

Table 4 Daily and annual disposed loads of Hijlan Springs Creek to the Euphrates River

\begin{tabular}{lcccc}
\hline Variables & $\begin{array}{c}\text { Conc. } \\
\mathrm{mg} / \mathrm{l}\end{array}$ & $\begin{array}{c}\text { Load. tons } \\
\text { /day }\end{array}$ & $\begin{array}{c}\text { Contaminants Load } \\
\%\end{array}$ & Total loads disposal \\
\hline $\mathrm{K}^{+}$ & 36 & 11.384 & 1.116 & \\
$\mathrm{Na}^{+}$ & 556 & 175.820 & 17.237 & \\
$\mathrm{Mg}^{++}$ & 207 & 65.458 & 6.417 & \\
$\mathrm{Ca}^{++}$ & 338 & 106.883 & 10.478 & Average Water Discharge (Q) \\
$\mathrm{Cl}^{-}$ & 1330 & 420.577 & 41.232 & $=316224 \mathrm{~m}^{3} /$ day \\
$\mathrm{SO}_{4}^{--}$ & 555 & 175.504 & 17.205 & \\
$\mathrm{HCO}_{3}{ }^{-}$ & 199 & 62.828 & 6.159 & \\
$\mathrm{NO}_{3}{ }^{-3}$ & 1 & 0.316 & 0.031 & \\
$\mathrm{PO}_{4}^{-3}$ & $<0.1$ & $<0.03$ & $<0.003$ & Total Load = Q x Conc. \\
$\mathrm{Cu}$ & 0.0041 & 0.001 & 0.00009 & $=\mathrm{m}^{3} /$ day $\mathrm{mg} / \mathrm{l} \times 10^{-6}$ \\
$\mathrm{Co}, \mathrm{Zn}, \mathrm{Pb}, \mathrm{Fe}$ & 0 & 0 & 0 & $=1020$ ton/day \\
$\mathrm{Mn}$ & 0.0068 & 0.002 & 0.00019 & $=372,300$ ton/year \\
$\mathrm{Cd}$ & 0.009 & 0.003 & 0.00020 & \\
$\mathrm{TSS}$ & 4 & 1.264 & 0.124 & \\
\hline
\end{tabular}

\subsection{Natural water Therapies and Aquaculture}

The subsurface litho-chemistry of the water-bearing horizons is a dominant factor that affects the chemistry of Hijlan springs water, where both dissolution and evaporation processes play a role 
in the enrichment of ions. Carbonate rocks (limestone, dolomitic limestone, and dolomite) of Ana and Euphrates Formations were partially dissolved, thus releasing $\mathrm{Ca}, \mathrm{Mg}$ and $\mathrm{HCO}_{3}$ into the aquifer. The high concentration of $\mathrm{Na}$ and $\mathrm{Cl}$ in the spring water is attributed to partial mixing of connate water with the meteoric water. Springs are resultant features of topography and crosscutting of the Abu Jir Fault Zone (Awadh and Abdul Al-Ghani, 2013; Bayan et al., 2020), where a set of aquifers are found along the fault planes. A Balneological water quality assessment was conducted according to the minero-medicinal Spa definitions (Jordana and Batista, 2004), since the chemical properties of the spring water and its mixing with the Euphrates water can significantly affect human health. According to Komatina (2004); Agishi and Ohatsuka, (1998), a minero-medicinal water can be classified based on total mineralization, ion concentrations and trace composition, acidity or alkalinity, and temperature. For Balneo-therapeutic assessment, some physicochemical parameters are compared with the well-known guidelines such as the European Union, (2009) and US Spas (Lund, 1996 and Eaton, 2004). Consequently, values of pH, TDS, TH, $\mathrm{Ca}^{+2}, \mathrm{Mg}^{+2}, \mathrm{Na}^{+}, \mathrm{SO}_{4}{ }^{=}, \mathrm{Cl}^{-}, \mathrm{HCO}_{3}{ }^{-}, \mathrm{NO}_{3}{ }^{-}, \mathrm{Pb}, \mathrm{Zn}, \mathrm{Fe}, \mathrm{Mn}, \mathrm{Cu}$, and $\mathrm{Cd}$ in the spring and the mixture of Hijlan Creek with the Euphrates waters are consistent with those of international Spas. Hence, the sample waters can be used for therapeutic purposes, beneficial for human well-being, and remedy for multiple diseases. The temperature of Hijlan water is described as being tepid to hypothermal $\left(21.2-25.6^{\circ} \mathrm{C}\right)$, which means it requires heating to be used as thermal water $\left(38-44^{\circ} \mathrm{C}\right)$ for therapeutic application (Matz et al., 2003). $\mathrm{H}_{2} \mathrm{~S}$ measurements of water flowing from Hijlan springs indicate a small amount of $\mathrm{H}_{2} \mathrm{H}$ dissolved in water which appears at $\mathrm{H} 1$ and fades away at H5 (Table 2). These concentrations could be beneficial in the use of Creek Hijlan water as a balneological therapy. Generally, the water of Hijlan Creek is unsafe to drink due to the higher concentration of major cations and anions in comparison to the standard limits set by the World Health Organization (WHO, 2011). 
Hijlan Springs Creek was assessed for aquatic life purposes using the physicochemical parameters, such as temperature and existent metals (iron, nickel, copper, zinc, cadmium, and lead), as provided by Svobodova et al., (1993). The recommended guideline limit values for fish farming including the optimal $\mathrm{pH}$ range of $6.5-8.5$ and a water temperature of approximately 15 ${ }^{\circ} \mathrm{C}$. The tepid hypothermal water of Hijlan springs is unsuitable for aquaculture, given that its nitrate content (about $1 \mathrm{mg} / \mathrm{l}$ ) is lower than the guideline limits, and the $\mathrm{H}_{2} \mathrm{~S}$ concentration $(1-2$ $\mathrm{mg} / \mathrm{l})$ exceeds the guideline limit (0.002). Based on the results, the Hijlan springs water appears unsuitable for fish farming. The toxic Fe content for fish cyprinid culture is accepted for concentrations less than $0.2 \mathrm{mg} / \mathrm{l}$. Therefore, the water of Hijlan Creek is acceptable since it has a Fe concentration of zero (0). The water is also healthy in terms of the concentration of $\mathrm{Ni}, \mathrm{Cu}$, $\mathrm{Zn}$, and $\mathrm{Pb}$, except for Cadmium, which exceeds the guideline limit.

\section{Conclusions}

This study focuses on an active hydrodynamic confluence zone with a water residence time of < 5 minutes, which is subjected to mixing of the water discharges of Hijlan Creek $\left(316,224 \mathrm{~m}^{3} /\right.$ day) and Euphrates River $\left(5.7 \times 10^{6} \mathrm{~m}^{3} /\right.$ day $)$. A mass transport plume of minero-medicinal water was detected at a distance of 150 meters from the mouth of the confluence, which acts as a single point source of 1020 tons/day discharge for total dissolved load into receiving water. Although the base flow water of Hijlan Creek is classified as minero-medicinal water and can be used for water therapeutic purposes, the Creek water discharge is considered a point source of pollution, which adds different contaminants of up to 372,300 tons/year. The discharged load attenuated downstream due to a mixing discharge rate of $5.5 \%$ from Hijlan Creek versus $94.5 \%$ from Euphrates River. Accordingly, the concentration dilution rate calculated from $\mathrm{Cl}^{-}$plume show that $92.9 \%$ of $\mathrm{Cl}^{-}$is derived from Hijlan Creek and $7.1 \%$ comes from the Euphrates upstream. The mixing-dilution processes within $\mathrm{DO}$ and $\mathrm{BOD}_{5}$ plumes were generated in a condition of 
self-purification factor equal to 0.25 , de-oxygenation coefficient $\left(\mathrm{k}_{1}\right)$ equals to $2.03 \mathrm{sec}^{-1}$ and reaeration coefficient $\left(\mathrm{k}_{2}\right)$ equals to $0.51 \mathrm{sec}^{-1}$.

Numerous Physico-chemical plumes were detected, including plumes originating from the Creek collector springs. Water temperature and other important water quality variables are used as a "tracer" to define the dilution-enrichment boundaries and the spatial distribution of their concentration within the mixing zone. The mass transfer of the TDS concentration within the mixing TDS plume as represented by a dilution gradient reached $10 \mathrm{mg} / \mathrm{l}$ per meter with the flow direction. The chemical mixing occurred when parcels of Creek brackish water meet parcels of the Euphrates freshwater under different water velocity conditions, causing changes of ionic concentration. Neutral water of Hijlan Creek mixed with slightly alkaline water of the Euphrates River forming a plume of $7.4 \mathrm{pH}$ in the confluence zone. It returns to its $\mathrm{pH}$ values as observed at the upstream site. Three anomalies of dissolved oxygen concentration plumes of 4.5 to $6.5 \mathrm{mg} / \mathrm{l}$ were observed at the same site of temperature plume. At the end portion of the DO plume the Euphrates water was oxygenated at the rate of $7.5 \mathrm{mg} / \mathrm{l}$ to create an opposite trend phenomenon of $\mathrm{BOD}_{5}$ concentration then decreases downstream reaching $1.8 \mathrm{mg} / \mathrm{l}$. The decreasing phenomenon in $\mathrm{BOD}_{5}$ values is attributed to the external input of oxygen from the solubilization of atmospheric oxygen and discharge dilution mechanism, where most of the chemical ions and trace elements concentration are highly influenced by river flow dilution.

\section{Acknowledgments}

The authors are deeply grateful for Prof. Bayan Muhie Hussien's significant contribution to this work. Prof. Hussien's passed away (may his soul rest in peace) during the final stage of this work. 


\section{References}

Abdul Razzak, M.I., \& Zaynal, M.S.(2012). The use of tri-geophysical methods for concealed karst cavities location near Haqlaniyah town. Iraqi J. of Science, 53(2), 341-352.

Agishi, Y., \& Ohatsuka, Y (1998) Presents features of Balneo therapy in Japan. Global Environ Res 2:177-185

Al Hadithi, Kh. I, (1994). Hydrology and Hydro geochemistry of Al Qadisiyia Reservoir Dam, Unpublished Thesis, Iraq, Baghdad University, College of Science. 208 p.

Al Hamdani, M.A., Fayadh, A. S., \& Hussien, B, M, (2010), Probable pollution study in Euphrates River between Qa'im and Falluja during (2007 - 2008) water years. Ministry of Higher Education and Scientific Research, University of Al -Anbar, Center of Desert Studies. Unpubl. Study

Al Hamdany, M. A., Fayadh, A. S., Hussien, B. M., Salim, S. A., \& Abed, M. A, (2012). Sources of Ions and Trace Elements in the water of Euphrates River from Qaem to Baghdadi (statistical study). I.B.G.M, ISSN 1811-4539. S.C OF G.S. M., 8(1).

Al Jabbari, M, H, Hassen, Q, M, Emad, M, A, (2002); National Programme in the best used of water resources within Euphrates basin. Ministry of Agriculture, Baghdad, 520 p.

APHA, (American Public Health Association), 2012. In: Eaton, A.D., Clesceri, L.S., Greenberg, A.E. (Eds.), Standard Methods for the Examination of Water and Wastewater, twentysecond ed. APHA, Washington, ISBN: 978-087553-013-0, p. 1360.

APHA, AWWA, WEF, (1995). Standard methods for the examination of water and wastewater, (19th edition), Washington.

Awadh, S. M, \& Abdul Al-Ghani, S, (2013). Assessment of sulfurous springs in the west of Iraq for balneotherapy, drinking, irrigation and aquaculture purposes. Environmental Geochemistry and Health, ISSN 0269-4042, DOI 10.1007/s10653-013-9555-6., 35 (4).

Barcelona J, Gibb, P, Helfrich A, Garske E, (1985). Practical Guide for Groundwater Sampling, EPA 600u2-85 104, US, Environmental Protection Agency, Robert S. Kerr Environmental Research Laboratory, Ada, OK, pp. 78 -80.

Bayan, M. H; Muwafaq, A. R and Husam, N. M. 2020. Estimation of Corrosion and Encrustation from Groundwater Chemistry of the Aquifers: A case study of Al Hammad Zone. Environmental Nanotechnology, Monitoring \& Management. https://doi.org/10.1016/j.enmm.2020.100334. 
Bayan, M.H., Muwafaq, A.R., Marwan, M.F. (2020). Characterization and behavior of Hydrogen Sulfide plume sreleased from activesulfide-tarsprings,Hit-Iraq. AtmosphericPollutionResearch. 11.894 -902.

Brikowski, T, (2011). Lab Notes, Hydrogeology Outdoor Laboratory. GEOS 4430, Geosciences Dept., U. Texas-Dallas, 51 p.

Consortium, Y, (1981). Regional hydro geological study for block No.5 (Rutba area) \& for block No.7 (Ramadi-Ana-K-160), Unpubl. Study. Ministry of Irrigation.

Cruz, M. A. S., Gonçalvez, A. A., de Aragão, R., de Amorim, J. R. A., de Mota, P. V. M., Srinivasan, V. S., et al. (2019). Spatial and seasonal variability of the water quality characteristics of a river in Northeast Brazil. Environmental Earth Sciences, 78, 68.

Delvigne, G. A. L. (1980). Natural reaeration of surface water. WL/Delft Hydraulics, Report on literature study R1149 (in Dutch), Delft, NL.

Eaton J (2004). Balneotherapy, hydrotherapy-therapeutic study. The healing properties of the Tecopa hot spring manual water. http://www.delightshotspringsresort,balneotherapy.

European Union. (2009). Directive 2009/54/EC of the European parliament and the council, of 18 June 2009, on the exploitation and marketing of natural mineral waters. Official Journal of the European Union, OJ L 164, p. 58.

Fayadh, A. S., Hussien, B. M., Al-Hamdani, M. A., Saifuldeen, A., Salim, S. A., Mukhlef, H. N, \& Abed, M. A, (2016). Hydrologic System of Euphrates River (Spatial Analysis) Between Qaem and Falluja. I.B.G.M, ISSN 1811-4539. SCGSM. 12(1) 1-18.

Fregoso-López, M.G., Armienta-Hernández, M.A., Alarcón-Silvas, S.G. et al. Assessment of nutrient contamination in the waters of the El Fuerte River, southern Gulf of California, Mexico. Environ Monit Assess 192, 417 (2020). https://doi.org/10.1007/s10661-02008354-7.

Gao, Y., Yu, J., Song, Y., Zhu, G., Paerl, H. W., \& Qin, B. (2019). Spatial and temporal distribution characteristics of different forms of inorganic nitrogen in three types of rivers around Lake Taihu, China. Environmental Science and Pollution Research, 26, 6898-6910.

Gurnell AM, Scott SJ, England J, et al. Assessing river condition: A multiscale approach designed for operational application in the context of biodiversity net gain. River Res Applic. 2020;120. https://doi.org/10.1002/rra.3673

Helsel, D.,\& Hirsch, R, (2002). Chapter A3, statistical methods in water resources. Techniques of Water-Resources Investigations of the United States Geological Survey, Book 4, Hydrologic Analysis and Interpretation, 510 p. http://water.usgs.gov/pubs/twri/twri4a3/ 
Hussien, B.M, (2010). Hydrogeological Condition within Al -Anbar Governorate.J. of Anbar Univ. for Pure Science, 4(3) 97-111.

Jena V, Dixit S, Gupta S. Assesment of Water Quality Index of Industrial Area Surface Water Samples Int. J. Chem, Tech. Res. 2013; 5(1):278-283.

Johnes, P.J., (2007). Uncertainties in annual riverine phosphorus load estimation: Impact of load estimation methodology, sampling frequency, base flow index and catchment population density. J. Hydro. 332, 241-258.

Jordana, S., \& Batista, E, (2004). Natural ground water quality and health. Geologia Acta 2(2):179-188.

Kiely, G. Environmental Engineering; McGraw Hill (U.K.) Ltd (1998).

Komatina, M. M, (2004). Medical geology: Effects of geological environments on human health (Vol. 2, p. 502). Amsterdam: Elsevier Science.

Langmuir, D., (1997). Aqueous Environmental Geochemistry, Colorado School of Mines. Prentice Hall. Upper Saddle River, New Jersey 07458, 618 p.

Little wood, I.G., \& Marsh, T.J., (2005). Annual freshwater river mass loads from Great Britain, 1975-1994: Estimation algorithm, database and monitoring network issues. J. Hydro., 304, 221-237.Water 2014, 6179

Lund, J (1996). Balneological use of thermal and mineral waters, 25(1). Elsevier Science, Great Britain, 103-147

Mahdi, A.H.I., Sissakian, V.K., Amin, R.M., Salman, B.S \& Hassan, F.A. (1985). Geological Report on the Haditha area. Part 1, GEOSURV, Int. Rep. No.1523.

Marta T, Damia B, Roma T. Surface Water Quality indices for the analysis of data generated by automated sampling networks. TrAc Trends. Anal. Chem, 2010; 29(1):40-52.

Mather, J. R, (1974). Climatology, Fundamental and application. Mc Graw Hill, USA.

Matz, H., Orion, E., \& Wolf, R. (2003). Balneotherapy in dermatology. Dermatologic Therapy, $16,132-140$.

Morel, F. M.M., \& Hering, J.G, (1993). Principles and Applications of Aquatic Chemistry. J. Wiley \& Sons, New York. 588 p.

Mullaney, J. R., Lorenz, D.L., \& Arntson, A.D., (2009). Chloride in Groundwater and Surface Water in Areas Underlain by the Glacial Aquifer System, Northern United States National Water-Quality Assessment Program, Scientific Investigations Report 2009-5086. U.S.G. S, Reston, Virginia. 
Muwafaq A. Rabeea; Ahmed S. Al-Rawi; Osama J. Mohammad; Bayan M. Hussien. (2020). The residual effect of fish farms on the water quality of the Euphrates River, Iraq. Egyptian Journal of Aquatic Biology \& Fisheries. 24(4): 549 - 561

Omole, D., \& Longe, E., (2012). Re-aeration Coefficient Modeling: A Case Study of River Atuwara in Nigeria. Research Journal of Applied Sciences, Engineering and Technology, 4, 1237-1243.

Pasquini, A.I., \& Sacchi, G.A., (2012). Hydrochemistry and nutrients dynamic in the Suquía River urban catchments, Córdoba, Argentina, Environ. Earth Sci, 65, 453-467.

Robert M. Bethea (1973) Comparison of Hydrogen Sulfide Analysis Techniques, Journal of the Air Pollution Control Association, 23:8, 710-713, DOI: 10.1080/00022470.1973.10469832. Shelton, L., (1994). Field Guide for collecting and processing stream- water samples for the National Water Quality Assessment Program. USGS Open-File Report 94-455. Sacramento, California. U.S. Geological Survey. NAWQA Field Technical Support. Placer Hall 6000J Street. Sacramento, Ca. 95819-6129.

Sissakian, V.K. and Fouad, S.F., 2012. Geological Map of Iraq, scale 1:1000000, 4th edition. Iraq Geological Survey Publications Baghdad Iraq.

Sissakian, V.K., \& AL-Mousawi, H, A. (2007). Karstification and related problems, examples from Iraq. Iraqi Bull of geology and mining, 3(2) 1-17.

Sissakian, V.K., \& Hafidh, S.Q. (1994). The geology of Haditha Quadrangle. GEOSURV, Int. Rep.no.2257.

Streeter, H., \& Phelps, H., (1925). A study of the pollution and natural purification of the Ohio River. U. S. Public Health Service .

Stumm, W., \& J.J. Morgan. (1981). Aquatic Chemistry. An Introduction Emphasizing Chemical Equilibria in Natural Waters. 2nd Edition. J. Wiley \& Sons, New York. 780 pp.

Svobodova, Z., Lloy, R., Machova, J., \& Vykusova, B. (1993). Water quality and fish health. EIFAC, technical paper 54, FAO, Rome, p. 71.

Techno promo export (1978). The project on the Euphrates River, Republic of Iraq, Technical Design, Vol.1, Natural condition, Moscow.

Tien Zubaidah, Nieke Karnaningroem, Agus Slamet. (2019). The Self-Purification Ability in the Rivers of Banjarmasin,Indonesia. Journal of Ecological Engineering,20(2): 177-182. https://doi.org/10.12911/22998993/97286.

Tuyet T.N. Nguyen; Julien Némery; Nicolas Gratiot; Josette Garnier; Emilie Strady; Dan P. Nguyen; Viet Q. Tran; An T. Nguyen; Son Tung Cao; Trang P.T. Huynh. Nutrient budgets 
in the Saigon-Dongnai River basin: Past to future inputs from the developing Ho Chi Minh megacity (Vietnam). (2020). River Research and Applications, 36(6): 974-990. https://doi.org/10.1002/rra.3552.

USEPA, (2000); National water quality inventory: 2000 report. EPA-841-R-02-001.

Van Pagee, J. A. (1978). Natural reaeration of surface water by the wind. WL/ Delft Hydraulics, Report on literature study R1318-II (in Dutch).

Vandana Singh; Nem Kumar Nagpoore; Jaichand; Alok Lehri. (2020). Monitoring and assessment of pollution load in surface water of River Ganga around Kanpur, India: A study for suitability of this water for different use. Environmental Technology \& Innovation, 18, 100676. https://doi.org/10.1016/j.eti.2020.100676.

Waite, T.; Freeman, N. Mathematics of Environment Processes. Lexington Books, London. (1977).

Wetzel, R.G. (1983). Limnology. 2nd Edition. Saunders College Publishing, Philadelphia. 767 pp.

WHO (2011) “Guidelines for Drinking-water Quality” 4th Edition, 541 p. WHO Library Cataloguing-in-Publication Data. (NLM classification: WA 675). Cover designed by WHO Graphics, Switzerland. Typeset by Value Chain, India. Printed in Malta by Gutenberg. 